\title{
ALKBH7 Gene
}

National Cancer Institute

\section{Source}

National Cancer Institute. ALKBH7 Gene. NCI Thesaurus. Code C106584.

This gene plays a role in oxidation. 